\title{
The Impact of Foreign Investment Flows on Global Linkages of \\ The Asian Emerging Equity Markets
}

\author{
Sunil Poshakwale ${ }^{1}$ and Chandra Thapa \\ Centre for Research in Economics and Finance, School of Management, Cranfield University, \\ Bedfordshire, MK43 0AL, England
}

\begin{abstract}
Evidence of the impact of foreign equity investment flows on the global linkages of the Asian emerging equity markets is provided. Findings confirm that there is a general trend towards greater integration and this process appears to be influenced by the increasing volumes of foreign equity portfolio investment flows. The results support the widely-held view that foreign investors are return chasers and their trading behaviour is based on information drawn from recent returns available in the emerging markets. The results also confirm the price-pressure hypothesis which suggests that foreign equity investors are mainly responsible for the increases in the stock market valuations in the Asian emerging markets. In view of the findings, the Asian emerging markets may become more vulnerable to the changes in foreign investment flows and turn more volatile in future.
\end{abstract}

Key words: Foreign equity investors; Asian emerging markets; Cointegration and VEC; Global Linkages and Short-run Dynamics

\footnotetext{
${ }^{1}$ Cranfield University, Cranfield, Bedford, England, MK43 0AL, Telephone:+44 (0) 1234754404, Fax: +44 (0) 1234 752554, Email:sunil.poshakwale@cranfield.ac.uk
} 
JEL Classification: G1, F3

\section{The Impact of Foreign Equity Investment Flows on Global Linkages of The Asian Emerging Equity Markets}

\section{Introduction}

The impressive growth in foreign equity investments in emerging markets and the debate on the likely implications for their integration with the global equity markets has prompted intense research interest in this subject matter. The current credit crises caused by the high defaults in the US sub-prime market and its spill-over effects to other economies in both developed and developing part of the world have further highlighted the need to investigate the role of foreign institutional investors in emerging stock markets. Although there are a number of studies which provide evidence of increasing integration of emerging markets with the global markets (Syriopoulos, 2007; Chelley-Steeley, 2005; Dungey et al, 2004), none have so far examined the role played by foreign investors on the long and short run financial linkages of emerging markets. In view of the global spread of current financial crisis and its likely implications for a number of emerging markets, it is both topical and theoretically desirable to understand the role and influence of foreign investors on the process of integration of emerging equity markets with the global markets.

This paper draws inspiration from two main strands of the literature. The first one deals with integration of emerging equity markets with the global equity markets by investigating the correlation structure and comovements in returns. There is a growing body of research that provides evidence on the extent to which equity markets around the world have become integrated (see for example, Chang, 2001; Kanas, 1998, 1999; Kwan, et al, 1995; Masih and 
Mashi, 1997; Corhay, et al, 1993, 1995, Dickinson, 2000; Gerrits and Yuee, 1999; Pymonen and Knif, 1998). Focussing on the global linkages of Australian equity market with equity markets of its major trading partners and using data prior to 1996, Roca (1999) examines the price linkages between the equity markets of Australia and other developed markets, particularly US, UK, Japan, Singapore and developing markets of Hong Kong, Taiwan and Korea. Their result only supports the short term dynamic linkages of the Australian equity markets with US and UK. Further, Dungey et al. (2004) reports that equity markets in Australia are influenced by shocks common to all other markets around the world. Their study concludes that the US market plays a significant role in explaining the Australian equity market's movement whilst Australia's domestic output has minimal impact on its own equity market. Yes in another investigation aimed at examining the linkages in stock indices amongst the US, European and Asia-Pacific developed markets, Hsin (2004) finds evidence consistent with extant findings of a strong linkage and transmission effects among the regional participants in Europe, such as Germany, Britain and France and Asia-Pacific markets of Japan, Australia, Hong Kong, and Singapore.

Evidence on integration of emerging equity markets with the developed markets is somewhat mixed. For instance, Chan et al. (1992) examine data for the Asian emerging markets and find that the markets are segmented. This finding is further supported by Lamba (2005) who uses data for the period 1997-2003 from the South Asian emerging markets and concludes that most of the markets in his sample are segmented. Further, Bekaert and Harvey (1995) measure the degree of integration using equity returns and conclude that some countries have become less integrated over time. In contrast to the findings mentioned above, there are a number of studies including one by Jong and Roon (2005) which show that emerging equity markets have become more integrated with the developed markets. In another recent study, Tai (2007) examines Asian 
emerging market data and concludes that these markets have become integrated with world capital markets since the time when these markets were first liberalised. Soydemir (2000) investigates the co-movements relationship between developed and emerging market economies using the economic fundamentals and trade linkages as the basis. He concludes that Mexico and USA show stronger linkages whereas Argentina and Brazil exhibit sign of weaker association and attributes the differences to the trade flows. However, Soydemir does not consider the shortrun dynamics and long run association of the trading activities of foreign investors, which has been reported as one of the key causes leading to the closeness of equity market (Errunza, 2001).

The second strand of literature deals with the dynamics of foreign investment flows and equity returns in emerging markets (see, Froot et al., 2001, Bekaert, et al., 2002, Richards, 2005). There are two main streams that flow from this body of research. The first seeks to enquire whether foreign equity investors are attracted by higher returns offered by foreign equity markets (see, Bohn and Tesar, 1996). The second attempts to investigate whether the impact of foreign equity flows on stock prices is permanent or just temporary as a consequence of the 'price pressure' exerted by these flows (see, Bekaert, et al 2002).

Despite the conjectures that foreign portfolio investors play an important role in increasing the global linkages (Errunza, 2001; Bekaert and Harvey, 2003 and Soyedemir, 2000), empirical evidence on the influence of foreign investors in the context of the global financial linkages of the Asian emerging markets is lacking. This paper fulfils the gap by bringing together these two strands of the literature and provides empirical evidence on the effect of foreign equity investment flows on the integration of the Asian emerging equity markets of India, Korea, 
Taiwan and Thailand with the global markets. ${ }^{2}$ Most previous studies use foreign equity flow data up to 2002. There is information which suggests that quite a few of the emerging markets, especially those in Asia, have introduced significant changes in the foreign ownership restrictions and have raised the limits on foreign ownership since $2001 .^{3}$ Given this, there is a need to investigate the extent of the impact foreign equity flows have had on the global linkages of the Asian emerging equity markets in more recent years. More recently, Rose and Li (2008) conducted a study using S\&P's Emerging Market Data Base on 34 emerging markets. They use the ratio of global and investable indices to show the impact of foreign participation on extreme comovements for the Asia Pacific Economic Cooperation. They use copula model with constant and time varying extreme correlation models and find affirmative result on the extreme movements in the APEC equity markets. Our study does not focus on extreme co-movements among these markets but on the role of foreign portfolio investor's trading activity on the longrun relationship and short-run dynamics with local equity markets. Our study not only shows the long run association and short run dynamic linkages of the emerging Asian equity markets with global counterparts but also provides evidence on the role played by foreign investors in driving the growth in the global linkages.

One of the reasons for relatively less research on this subject matter is that good quality high frequency data on foreign equity flows for emerging markets is not easily available. Thus previous research by Froot et al. 2001 uses proprietary data for equity flows from State Street Bank and Trust whilst Bakaert et al., 2002 have had to rely on monthly capital flow data for their research that involved 20 emerging markets. The foreign equity flow data in this paper uses the

\footnotetext{
${ }^{2}$ Our choice of markets is restricted by the lack of availability of good quality daily data on other emerging equity markets.

${ }^{3}$ For instance, Taiwan increased the foreign equity ownership limit to $75 \%$ in 2000 from $50 \%$ in 1999 before removing any limit towards the end of 2000.
} 
same source as the one used by Richards (2005) but with two significant differences. First, we use more recent data (from 2001 to 2007) so that the impact of more recent increases in the foreign equity ownership limits can be captured in the integration process of emerging equity markets. Second, unlike Richards (2005), instead of measuring integration with the US equity market, we use MSCI World Equity Market returns as a proxy for global markets because the foreign equity flow data from CEIC is aggregated and includes foreign investments from different countries including the US. Thus our paper provides evidence with respect to the integration of emerging equity markets globally rather than with the US market alone. The data used on foreign equity investments is daily which allows us to investigate long-run stochastic equilibrium relationship as well as short term dynamics. As our objective is to understand the dynamics of foreign equity investments not only on long term basis but also on the short-run dynamics, the use of aggregated daily foreign portfolio investments rightly justifies the use of high frequency daily data. Also except Richards (2005), no other paper has used high frequency data in integration studies.

Our research has important theoretical and policy implications. The rolling correlation of the Asian emerging market equity returns with the world market returns has grown over the years (see figures 1,2, $3 \& 4$ ). Further, the interest of foreign investors in these markets has also grown with time (see investment flow figures in Table 1). These developments will have significant impact on asset pricing and portfolio allocations. Historically, one of the main motivations for investing in emerging markets was that these markets had low correlations with developed markets. However, if the present magnitude and pace of foreign investments are sustained over time then the emerging markets would become fully integrated with the global markets. This may have detrimental effect on diversification of risk since emerging equity markets have long 
been viewed by international investors as segmented markets offering excellent diversification benefits to international investors (see Chatrath et al., 1996). Further, there is research evidence that increased foreign equity flows seems to cause greater volatility in the emerging equity markets which is a matter of concern to the policy makers. ${ }^{4}$ Thus the impact of increasing foreign equity investment flows on the integration of emerging equity markets is of high interest to both academics and policy makers. This is particularly relevant since there is evidence to suggest that foreign investors appear to have short-term investment horizon and at the sign of the slightest of trouble, the foreign capital tends to leave at a much greater pace than the pace at which it arrives in emerging markets (see, Bekaert, Harvey and Lumsdaine, 2002).

Our paper makes three important contributions to the existing literature. First, we extend the literature by investigating both the long and short-run dynamics of the impact of foreign equity investment flows on global integration of the selected Asian emerging markets. Second, we use more recent foreign equity flow and return data to capture the effect of increased foreign investment activity in emerging markets as a result of further relaxation of foreign ownership restrictions. Finally, unlike previous studies we use MSCI world return index that comprise twenty-three stock markets of industrialized countries which is a better proxy for measuring the dynamics of global linkages.

\footnotetext{
${ }^{4}$ There are several examples of interventions by policy makers concerned with the negative impact of foreign equity flows. For instance, Malaysia imposed capital controls in 1998 following the Asian financial crisis with an aim to control the excessive volatility that appears to have been caused by a rapid outflow of foreign capital. In December 2006 , the Thai government tried to impose tough controls by requiring investors with more than $\$ 20,000$ of investment to remain invested for a minimum period of one year or face severe penalties if this investment is removed within a year. However, the government had to reverse this decision following a steep fall in the stock market after shares suffered their worst daily fall in 16 years and closed down $14.8 \%$.
} 
Our findings suggest that the foreign equity investment flows contain significant information in explaining the short-run dynamics and long-run relationship of the selected Asian emerging equity markets with the global markets. Our results are robust in terms of synchronization and statistical sensitivity of VAR based VEC and cointegration tests. We conclude that the rapid growth in the flow of foreign equity flows is leading to greater integration of the Asian emerging equity markets with the global equity markets. This may have significant implications for pricing of assets and international portfolio allocations.

The rest of the paper is organized as follows. The following section provides details of data and methodology used in this study. Section 3 documents the empirical findings, and Section 4 concludes the paper.

\section{Data and Methodology}

\subsection{Data}

We use daily data in our analysis for a sample period of six years beginning 1 January 2001 to 30 March 2007. We have segregated the data in two sub-samples to observe any time varying impact as we note significant increase in the foreign equity investment flows in 2004-2007 period (see Table 1). Daily returns are calculated from the MSCI global total return index which is a composite index of 23 developed markets and the MSCI total return emerging market indices denominated in US\$ for India, Korea, Taiwan, and Thailand. ${ }^{5}$ Our choice of emerging markets was restricted because of lack of availability of daily equity portfolio investment data for other emerging equity markets. A further reason is that a considerably long period has elapsed since these countries opened up their equity markets for foreign investments. Therefore, it is both

\footnotetext{
${ }^{5}$ Since our Net Foreign Equity Investment (NFEI) data represents total of all foreign portfolio investments, we use the MSCI world index as proxy of global equity returns.
} 
timely and appropriate to investigate the influence of foreign equity investments given the rapid increase in the investment flows in more recent periods. The MSCI indexes have been obtained from DataStream international and net daily foreign equity portfolio investment data is obtained from CEIC.

\subsection{Methodology}

We take a non structural approach for investigating the impact of foreign equity investment flows on the short and long run dynamics of Asian equity markets with the global markets. ${ }^{6}$

Our analysis utilizes cointegration and vector error correction models. Cointegration approach is widely used for examination of long-run stochastic relationship between equity markets (see Kearney and Lucey, 2004 for a comprehensive review). For short-run dynamics, the use of Vector Autoregression (VAR) analysis is quite widespread (see, Froot et al, 2001, Bekaert, Harvey and Lumsdaine, 2002, and Richard, 2005).

\subsubsection{Cointegration}

We examine the long run relationship using VAR-based cointegration approach proposed by Johansen (1988) and Johansen and Juselius (1990). The Johansen-Juselius (JJ) approach is preferred because it is considered superior to regression-based approach suggested by Engle and

\footnotetext{
${ }^{6}$ Use of a non-structural approach in linkage studies is advocated by Bekaert and Harvey (2000) who suggest that because of lack of theoretical basis, non-structural approach should be preferred in conducting portfolio flow studies. Further, Tesar and Werner (1995) report that even in the relatively open markets, the substantial increase in cross border flows do not comply with the theoretical foundations of optimal portfolio theory due to home bias effects.
} 
Granger in $1987 .^{7}$ The JJ approach uses maximum likelihood estimates and allows testing and estimation of more than one cointegrating vector in the multivariate system without requiring a specific variable to be normalized. This way, the $\mathrm{JJ}$ test overcomes the problem of carrying over the errors from the first step into the second step commonly encountered in Engle and Granger's (1987) approach. Further, Johansen's method is independent of the choice of endogenous variable within a vector autoregression (VAR) framework. This enables testing for various structural hypotheses involving restricted versions of cointegrating vectors and speed of adjustment parameters using likelihood ratio tests. The general VAR equation can be rewritten as;

$$
\begin{aligned}
& y_{t}=A_{1} y_{t-1}+A_{2} y_{t-2}+\ldots \ldots \ldots \ldots . . .+A_{p} y_{t-p}+\varepsilon_{t} \\
& \Delta y_{t}=\Pi y_{t-1}+\Gamma_{1} \Delta y_{t-1}+\Gamma_{1} \Delta y_{t-2}+\ldots \ldots . .+\Gamma_{p-1} \Delta y_{t-p+1}+\varepsilon_{t} \\
& \Delta y_{t}=\Pi y_{t-p}+\sum_{i=1}^{p-1} \Gamma_{i} \Delta y_{t-i}+\varepsilon_{t}
\end{aligned}
$$

Where:

$$
\begin{aligned}
& \Pi=\sum_{i=1}^{p} A_{i}-I, \text { and } \\
& \Gamma_{i}=-\sum_{j=i+1}^{p} A_{j}
\end{aligned}
$$

Since our objective is to investigate the long-run relationship, we will focus on the elements of matrix $\Pi$. If vector $y$ contains $\mathrm{m}$ variables, matrix $\Pi$ will be of the order $\mathrm{m} x \mathrm{~m}$, with a maximum

\footnotetext{
${ }^{7}$ The Johansen-Juselius procedure resolves the problem of endogeneity in that we do not need to normalise the cointegrating vector on one of the variables as required in the Engle and Granger (EG) test (see Cheung and Lai, 1993).
} 
possible rank of $m$ (or full rank). Equation (3), except for the $\Pi y_{t-p}$ term, is in the form of the traditional VAR with first difference. The $\Pi$ term determines whether the system of equations is cointegrated, i.e., whether a long-run equilibrium relationship exists. The feature to note is that the rank of matrix $\Pi$ is equal to the number of independent cointegrating vectors. If rank of matrix $\Pi=0$, the matrix is null, i.e., all the elements in this matrix are zero, which implies no cointegration or a lack of a long-run equilibrium relationship and the error correction mechanism, $\Pi y_{t-k}$, therefore, does not exist. In determining the rank of matrix $\Pi$ (number of cointegrating vectors), we calculate the characteristic roots or eigenvalues $\hat{\lambda}_{i}$ of $\Pi$. Johansen (1988) and Johansen and Juselius (1990) propose trace $\left(\lambda_{\text {trace }}\right)$ and maximum eigenvalue $\left(\lambda_{\max }\right)$ test statistics to establish whether the characteristic roots are significantly different from zero. The likelihood ratio (LR) statistic for the trace test $\left(\lambda_{\text {trace }}\right)$ is:

$$
\lambda_{\text {trace }}(r)=-T \sum_{i=r+1}^{m} \ln \left(1-\hat{\lambda}_{i}\right)
$$

Where $\hat{\lambda}_{i}$ are the estimated values of the characteristic roots (also known as eigenvalues) obtained from estimated $\Pi$ matrix. The null hypothesis to be tested is that the number of cointegrating vectors is less than or equal to $r$ against the alternative hypothesis that the number of cointegrating vectors is more than $r$. For example the null hypothesis $r \leq 0$ against alternative $r=1, r \leq 1$ against alternative $r=2$, and so forth. The 'maximum eigenvalue' test is used to evaluate the null hypothesis of $r$ cointegrating vectors against the $r+1$ cointegrating vectors. The LR test statistic is given by:

$$
\lambda_{\text {max }}(r, r+1)=-T \ln \left(1-\hat{\lambda}_{r+1}\right)
$$


The computed values of $\lambda_{\text {trace }}$ and $\lambda_{\max }$ statistics are evaluated using the critical values provided by Osterwarld-Lenum (1992). The optimal system lag length is determined by using the Schwarz Information Criteria (SIC). Specifically, the appropriate number of lags for each variable is obtained by computing the SIC over different lag schemes within a range of 1 to 20 and by choosing the number of lags that yields the lowest value for the SIC.

\subsubsection{Error Correction Representations}

Vector Error Correction Model (VECM) is employed on the cointegrated return series as this provides us with an effective way to analyze the short-run relationship including causality and the speed at which the error is corrected for establishing the long-run relationship found in the cointegration analysis. If variables are cointegrated they tend to converge in the long-run despite short-run deviations. VECM examines this equilibrium relationship and provides a feedback mechanism, the error correction term, which gradually moves in tandem with the equilibrium relationship. VECM also provides the mechanism to identify the magnitude and length of information being transmitted from one series to another through the system, referred as variance decomposition and impulse response function respectively. The VECM is employed on first difference of I(1) variables as shown below.

$$
\Delta y_{t}=\sum_{\mathrm{i}=1}^{\mathrm{m}} \beta_{11} \Delta \mathrm{x}_{\mathrm{t}-\mathrm{i}}+\sum_{\mathrm{i}=1}^{\mathrm{m}} \beta_{12} \Delta \mathrm{w}_{\mathrm{t}-\mathrm{i}}+\beta_{3} z_{t-1}+\mu_{t}
$$

Equation (8) is a three variable model with $\mathrm{y}$ and $\mathrm{x}$ being return series and $\mathrm{w}$ being the net foreign equity investment. The other representations with $\Delta x$ and $\Delta w$ could be similarly presented. The cointegrating vector $z_{t-1}$ is the error correction term which will be I (0) if the above series in their level term have long-run equilibrium relationship. This term corrects the 
short-term deviations and helps convergence of the series towards a long run equilibrium state. The parameter $\beta_{3}$ measures the speed of adjustment in the short term deviations whilst $\beta_{11}$ and $\beta_{12}$ capture the short run causality. The lag length and coefficients are determined by OLS regression.

\subsubsection{Impulse Response Function}

Impulse response function explains the responsiveness of one variable in the VAR framework to the shocks in its own as well as other variables. It explains the extent to which a unit shock in one variable in isolation of the others affects the movement in other variables. In each of the equation, one unit shock is applied to detect the change in the VAR system over time by representing the VAR as VMA (Vector Moving Average) representation:

$$
R i, t=b_{11}^{0} \varepsilon_{i, t}+b_{11}^{1} \varepsilon_{1, t-1}+b_{12}^{1} \varepsilon_{2, t-1}+\ldots \ldots
$$

Where, $b_{i j}$ are unit normalized innovation coefficients of impulse response function following the normalization by the Cholesky factor ${ }^{8}$ and $b_{11}^{0}$ is the simultaneous effect of a unit shock to $\varepsilon_{i, t}$. The contemporaneous innovation is stated in standard deviation form and have non-unit coefficient in contrast to its unit coefficients in the equation.

\subsubsection{Forecast Error Variance Decomposition}

Previous research has shown that variance decomposition analysis is quite effective in examining dynamic interactions amongst economic time series (Lutkepohl and Reimers, 1992). Whilst the impulse response function traces the effects of a shock in one endogenous variable on other

\footnotetext{
${ }^{8}$ See Diebold (2004).
} 
variables in the VAR, variance decomposition enables further analysis by decomposing the forecast error variance of domestic return index and net foreign equity investment that will provide us with a quantitative measure of the short run dynamic relationship among the variables. The variance decomposition thus offers greater insights on the relative significance of each random innovation that affects the variables in VAR by showing the proportion of changes in variance caused by a shock in its own lags and by shocks in variance of other variables as well as the magnitude of the effects.

\section{Empirical Findings}

First we use rolling correlations and JJ cointegration methods for examining the long-run relationship. Subsequently, we report the findings on short term feedback dynamics using different variants of the error correction model. With an aim to establish whether the pick-up in the foreign equity investments in more recent years following the impressive growth shown by the Asian equity markets provides greater empirical support to our hypothesis, the total sample is split into two parts. ${ }^{9}$ Table 1 provides descriptive statistics for the returns series and the foreign equity investment flow. Over the full sample period, highest daily returns are offered by Korea followed by Thailand, India and Taiwan. All four Asian markets offer much higher daily returns compared to the returns of the MSCI developed market index. The trend is generally similar across the two sub-sample periods with the exception that returns offered by Thailand and Taiwan in the second sub-period are lower than returns in the developed markets. Higher returns in emerging markets do not come without risk as the standard deviations of returns are much higher

\footnotetext{
${ }^{9}$ The first sub-period covers Jan 2001 to Dec 2003 and the second sub-period uses data for Jan 2004 to March 2007. The growth of foreign equity investment flows is evident from Table 1 which shows that the average equity investment flows more than doubled in the second period of the sample. The average net daily foreign equity investment rose to US\$98.33m during the period 2004-07 compared to US\$45.57m for the period 2001-03.
} 
for the Asian emerging markets. The returns are not normal and show significant kurtosis. The average daily foreign equity investment flows are much higher in the second sub-period. Taiwan leads the other markets in terms of foreign equity investment flows followed by India, Thailand and Korea.

\section{….....Insert Table 1 here......... \\ ........Insert Figures 1, 2, 3, \& 4 here........}

\subsection{Results on Long-run Relationship}

Table 2 presents the unconditional correlation coefficient between the domestic returns of the Asian emerging markets and MSCI world index. There is an indication of a move towards greater correlations from the first-sub period to the second sub-period for all markets with India and Thailand, in particular demonstrating relatively greater convergence in market movements. We present the rolling correlations for the four emerging markets with the global market in Figures 1 to $4 .^{10}$ It is evident that though the correlations are not stable over time, a general trend of increasing correlation is evident. The correlations appear to have increased significantly from 2004 onwards which is confirmed from the increase in correlation in the second sub-period as shown in Table 2 . Thus, the observed rise in correlation may partly be explained by the increase in the trading activity of foreign investors. This result is consistent with those reported by Phylaktis and Ravazzolo (2002) who also find statistically significant correlations amongst the emerging Asian markets and the US.

..Insert Table 2 here.........

\footnotetext{
${ }^{10}$ Several papers have used rolling correlations in investigating the equity markets integration. For instance, Lucey and Kearney (2004) use rolling correlations and conclude that they provide a good indication whether markets are integrated or segmented.
} 
Next, we employ the cointegration analysis which is a more robust approach in testing for longrun equilibrium relationship. All series including the net foreign equity flow series are integrated of order I(1) whilst their first differences are integrated of order I(0). For adding robustness to our unit root test, we have reported the results from three different unit root tests. The Augmented Dicky Fuller Test statistics is reported in panel A of table 3. As expected, all the test statistics are significant at $1 \%$ and $5 \%$ significance level for the first difference whereas the null of unit root cannot be rejected at level. Further the Philips Perron (PP) test was also applied, again testing the null of unit root. PP tests include an automatic correction to the Dicky Fuller procedure allowing for the auto correlated residuals. As shown in panel B, the results are similar and all the series have been found to have unit root in their level with no unit root in their first difference series. Unit roots tests has always criticized for lacking power and so we also conducted the KPSS test testing the null of no unit root. The results with the alternative procedure are same. The null of no unit root cannot be accepted in level series whereas the first difference null is accepted. For the ADF and PP tests, lag selection is based on the minimization of SIC. KPSS tests were conducted up to 10 lags, however to save space, only $1^{\text {st }}$ and $10^{\text {th }}$ lag findings are reported.

\section{........Insert Table 3 here.........}

Table 4 reports result of bivariate cointegration between the emerging Asian market returns and MSCI world index returns for the full sample period as well for the two sub-sample periods. For the full sample, one cointegrating vector is found for India and Taiwan whereas no cointegration is reported for Korea and Thailand. Further analysis reveals that whilst no cointegration is found for the first sub-period, results for the second sample period are similar to the full sample period and statistically significant cointegrating vectors are found for India and Taiwan. The results show strong signs of convergence of the Indian and Taiwanese markets with the global markets. 
The greater degree of integration found for the second sample period coincides with the significant increase in the average foreign equity investment flow for India and Taiwan. The average foreign equity investment flows for India and Taiwan increased to US\$36.65 million and US\$54.19 million from US\$9.841 million and US\$33.22 million respectively. In comparison, the foreign equity investment flow did not show any increase in the case of Korea and a relatively small increase in the case of Thailand.

\section{........Insert Table 4 here........}

Next, we present cointegration analysis results where we include foreign equity investment flow series with emerging market and world market return series. This analysis will provide us with the relative contribution of the foreign equity investment flow in the long-run relationship reported in Table 4. The results of the tri-variate cointegration are reported in Table 5. Both the trace and max trace statistics are significant for the full sample period as well as the two subsample periods. With the inclusion of foreign equity flow, at least one cointegrating vector is reported for all four markets thereby confirming that the integration process is driven by the activities of foreign investors. For India, Taiwan and Thailand two significant cointegrating vectors are found for the second sample period confirming the influence of foreign equity flows in the integration process. A summary of the main findings of the cointegration analysis is further provided in Table 6. 


\subsection{Results on Short-term Dynamics}

As previously discussed, the error correction provides feedback mechanism that measures the effect of a shock in one series as a result of a shock in another series in the VAR system. ECM can only be applied on cointegrated series. Since our cointegration analysis results show that all four markets are cointegrated only when foreign equity investment flows are included, we include the foreign equity investment flow data in the ECM analysis. Four variations of the ECM analysis are reported. The first variation is the block exogeneity Wald test that measures the statistical significance of the flow of information between the variables in the form of Granger causality. The second is the error correction term which shows the magnitude and speed of short-term adjustment. Third is the decomposition of the error variance which provides a quantitative measure of the short-run dynamic flow of information explaining the $h$-step ahead error variance in one variable due to transmission of shock in another variable in the VAR system. Finally, the impulse response shows the time and direction of the effect of shocks between the variables.

Table 7 presents the Granger causality and Error Correction Term (ECT) for each market. It is evident that the world market has significant causal impact on the return index of emerging markets as well as on the flow of net foreign investments. In contrast, none of the emerging markets seem to have any causal effect on the world market returns. These findings are consistent with previous literature that has demonstrated that shocks from developed markets have significant impact on the Asian emerging markets (see for example, Dungey, 2004). Further, we find that net foreign equity investment flows Granger cause returns in India, Taiwan and Thailand but no causality is found for Korea. 
Table 7 also reports the Error Correction Term (ECT) for all four markets as well as the foreign equity investment flows which are statistically significant implying that the short-term deviations in the integration process of the emerging markets with global markets are being corrected. The significant ECT for net foreign investment flows for all four markets confirms the considerable influence of foreign investment flow in correcting the short-term deviations in the integration process.

\section{........Insert Table 7 here.........}

The results are consistent with the price pressure hypothesis suggesting that foreign equity investors are mainly responsible for the increase in the stock market valuations in the Asian emerging markets. This suggests that the Asian emerging markets may become increasingly vulnerable to the shocks in the volume of foreign equity investment flows and thus become more volatile in future. This is a matter of concern to policy makers in emerging markets and, as a consequence some countries have attempted to restrict the flow speculative investment flows in their equity markets. ${ }^{11}$ Our results concerning the price pressure hypothesis are similar to those reported by Richards (2005) and much more pronounced than the ones documented by Froot et al (2001) for the Asian emerging markets. The results also confirm the positive feedback hypothesis since it is clear that returns from emerging markets Granger cause the foreign equity investment flows, a finding similar to the ones reported in Froot et al (2001) and Bekaert et al (2002). The

\footnotetext{
11 On 16 October 2007, India's stock market regulator proposed restricting the use of offshore participatory notes (PNs). PNs are much favoured by foreign investors, especially hedge funds who have been mainly responsible for US\$90bn investment in PNs. In reaction to this news, the Indian stock market promptly fell 9 per cent, triggering a temporary halt to trading.
} 
findings further confirm that foreign investors are high-return chasers and extract information from recent returns.

Variance decomposition analysis presented in Table 8 shows that in the case of India, a significant proportion of error variance is explained by the world market returns and its share of error variance increases over time. In fact, its magnitude of explanation for the 20 day-ahead forecast variance is equal to the proportion explained by the variance in its own returns. For Korea and Taiwan, similar results are found which confirm the significant role of global markets in explaining the returns in the Korean and Taiwanese markets. For India, the proportion of variance explained by the net foreign equity flow is small but increases over time from $3 \%$ for a 1 day-ahead forecast to $6 \%$ for the 20 day-ahead forecast. The foreign equity flows also seem to explain a large proportion of return variance of Taiwanese and the Thai markets. However, they have negligible share in explaining the error variance in the case of Korea. Overall, the variance in net foreign equity flows is significantly explained by world equity market returns which suggest that external shocks may significantly explain the volatility of foreign investments in emerging markets.

\section{….....Insert Table 8 here.........}

Figures 5 to 8 present findings of impulse response function analysis. In all cases, a unit cumulative innovation in world market returns has a significant and positive impact on the returns for all four markets. Innovations in net foreign investment flows also show strong and instantaneous effect in all markets. This evidence of contemporaneous price impact is consistent with the one reported by Richards (2005) and is much stronger is much stronger than the one documented by Froot et al (2001). The second set of figures present the response of net foreign 
investment flows to the lagged returns available in emerging markets as well as lagged investment flows and world market returns. The findings confirm the positive feedback hypothesis that foreign investor's activities are significantly influenced by the returns available in emerging markets.

\section{…....Insert Figures 5, 6, 7 and 8 here........}

\section{Conclusions}

The paper investigates the impact of foreign equity investment flows on the integration of the emerging markets with the global markets. We use daily net foreign equity investment flow and stock index return data available for the four Asian emerging markets of India, Korea, Taiwan and Thailand for 2001-2007 and employ a number of econometric tests for examining the longrun and short-run relationship with the global markets. Our findings suggest that greater integration of the Asian emerging markets with the global equity markets appears to be influenced by the increasing investments by foreign investors. Analysis of short-run impact confirms that the global markets have a significant causal impact on returns of all four emerging markets. More notable is the finding that foreign equity investment flows play a significant role in correcting the short-term deviations in the convergence process of Asian emerging equity markets with the global equity markets. Whilst the results are consistent with previous research, we find stronger evidence for the positive feedback hypothesis for all four markets. The results support the widely-held view that foreign investors are return chasers and their trading behaviour is based on information drawn from recent returns available in the emerging markets. The results also confirm the price- pressure hypothesis which suggests that foreign equity investors are mainly responsible for the increases in the stock market valuations in the Asian emerging markets. In 
view of the empirical evidence presented in this paper, the Asian emerging markets may become increasingly vulnerable to the shocks in the volume of foreign equity investment flows and turn more volatile in future. 
References

Bekaert, G. and. Harvey, C. R. (1995) Time-varying world market integration, The Journal of Finance, 50, 403-444.

Bekaert, G. and Harvey, C. R. (2000) Foreign speculators and emerging equity markets, The Journal of Finance, 55, 565- 613.

Bekaert, G. and Harvey, C. R. (2003) Emerging markets finance, Journal of Empirical Finance, $10,3-55$

Bekaert, G., Harvey, C. R. and Lumsdaine, R. L. (2002), The dynamics of emerging market equity flows, Journal of International Money and Finance, 21, 295-350.

Bohn, H and Tesar, L.L. (1996) U.S equity investment in foreign markets: Portfolio rebalancing or return chasing?, The American Economic Review, 86, 77-81.

Chan, K. C., Gup, B. E. and Pan, M. (1992) An empirical analysis of stock prices in major Asian markets and the United States, The Financial Review, 27, 289-307.

Chang, T. (2001) Are there any long-run benefits from international equity diversification fro Taiwan investors diversifying in the equity markets of its major trading partners, Hong Kong, Japan, South Korea, Thailand and the US, Applied Economics Letters, 8, 441-46.

Chatrath, A., C, Ramchander, S and Song, F. (1996) Benefits from portfolio diversification into the Indian equity market, American Business Review, 1-10. 
Chelley-Steeley, P. L. (2005). Modelling equity market integration using smooth transition analysis: A study of Eastern European stock markets. Journal of International Money and Finance, 24, 818 - 831

Cheung, Y. and Lai, K. S. (1993) A fractional cointegration analysis of purchasing power parity, Journal of Business \& Economic Statistics, 11, 103-223.

Corhay, A., Rad, A. T. and Urbain, J. P (1993) Common stochastic trends in European stock markets, Economic Letters, 42, 385-90

Corhay, A., Rad, A. T. and Urbain, J. P (1995) Long-run behaviour of Pacific-Basin stock prices, Applied Financial Economics, 5, 11-18

Dungey, M., Fry, R. and Martin, V. L. (2004) Identification of common and idiosyncratic shocks in real equity prices: Australia, 1982-2002, Global Finance Journal, 15, 81-102.

Dickinson, D. G. (2000) Stock market integration and macro economic fundamentals: an empirical analysis, Applied Financial Economics, 10, 261-76

Diebold, F. X. (2004) Elements of Forecasting, (3rd Ed.) Thompson: South Western, Ohio, USA

Errunza, V. (2001) Foreign portfolio equity investments, financial liberalization, and economic development. Review of International Economics, 9, 703 - 726

Engle, R. F and Granger, C.W.J. (1987) Co-integration and error correction: Representation, estimation and testing, Econometrica, 55, 251- 276. 
Froot, K. A, O'Connel, P.G.J and Seasholes, M.S. (2001) The portfolio flows of international investor, Journal of Financial Economics, 59, 151-193.

Gerrits, R. J. and Yuee, A. (1999) Short and long-term links among European and US stock markets, Applied Financial Economics, 9, 1-9

Hsin, C. (2004) A multilateral approach to examining the comovements among major world equity markets. International Review of Financial Analysis, 13, 433 - 462

Johansen, S. (1988) Statistical analysis of cointegration of cointegrating vectors, Journal of Economic Dynamics and Control, 12, 231-254.

Johansen, S. and Juselius, K. (1990) Maximum likelihood estimation and inference on cointegration - with applications to the demand for money, Oxford Bulletin of Economics and Statistics, 52, 169-210.

Jong, F de and Roon, F.A de. (2005) Time varying market integration and expected returns in emerging markets, Journal of Financial Economics, 78, 583-613.

Kanas, A. (1998) Long-run benefits from international equity diversification: a note on the Canadian evidence, Applied Economics Letters, 5, 659-63

Kanas, A. (1999) A note on the long-run benefits from international equity diversification for a UK investor diversifying in the US equity market, Applied Economics Letters, 6, 47-53

Kearney, C. and Lucey, B. M. (2004) International equity market integration: Theory, evidence and implications, International Review of Financial Analysis, 13, 571-583. 
Kwan, A. C. C, Sim, A, B. and Cotsomitis, J. A. (1995) The causal relationships between equities on world exchanges, Applied Economics, 27, 33-37

Lamba, A. (2005) An analysis of the short and long-run relationships between South Asian and developed equity markets, International Journal of Business, 10, 383-402.

Li, X. M and Rose, L. C. (2007) Market integration and extreme co-movements in APEC emerging equity markets, Applied Financial Economics, 18, 99 - 113

Lutkepohl, H and Reimers, H. (1992) Impulse response analysis of cointegrated systems, Journal of Economic Dynamics and Control, 16, 53-78.

Masih, A.M.M. and Mashi, R. (1997) A comparative analysis of the propagation of the market fluctuations in alternative models of dynamic causal linkages, Applied Financial Economics, 7, 59-74

Osterwald-Lenum. M. (1992) A note with quartiles as the asymptotic distribution of the maximum likelihood cointegration rank test statistics, Oxford Bulletin of Economics and Statistics, 54, 461-472.

Phylaktis. K. (1999) Capital market integration in the Pacific Basin region: An impulse response analysis, Journal of International Money and Finance, 18, 267-287.

Phylaktis, K. and Ravazzolo, F. (2002) Measuring financial and economic integration with equity prices in emerging markets, Journal of International Money and Finance, 21, 879903. 
Pynnonen, S. and Knif, J (1998) Common long-term and short-term price memory in two Scandinavian markets, Applied Financial Economics, 8, 257-65.

Richards. A. (2005) Big fish in small ponds: The trading behaviour and price impact of foreign investors in Asian Equity Markets, Journal of Financial and Quantitative Analysis, 40, 1-27.

Roca, E. D. (1999) Short-term and long-term price linkages between the equity markets of Australia and its major trading partner, Applied Financial Economics, 9, 501-511

Soydemir, G. (2000) International transmission mechanism of stock market movements: evidence from emerging equity markets, Journal of Forecasting, 19, 149 - 176.

Syriopoulos, T. (2007) Dynamic Linkage between Emerging European and Developed Stock Markets: Has the EMU any impact? International Review of Financial Analysis, 16, 41 - 60

Tai. C. S. (2007) Market Integration and contagion: Evidence from Asian emerging stock and foreign exchange markets, Emerging Markets Review, 8, 264-283

Tesar, L. and Werner, I. (1995) U.S. equity investment in emerging stock markets, World Bank Economic Review, 9, 109-130. 
Table 1

Descriptive Statistics

\begin{tabular}{|c|c|c|c|c|c|c|c|}
\hline \multicolumn{8}{|l|}{ Panel A } \\
\hline \multicolumn{8}{|c|}{ Full Sample $(01 / 01 / 2001-30 / 03 / 2007)$} \\
\hline \multicolumn{8}{|c|}{ Daily Average Net Foreign Equity Portfolio Investment (USD Millions) } \\
\hline Korea & 2.127 & 0.592 & 94.176 & -91.166 & 15.180 & 0.324 & 8.871 \\
\hline India & 23.764 & 10.387 & 776.766 & -633.596 & 73.495 & 1.709 & 31.506 \\
\hline Thailand & 2.965 & 0.000 & 394.502 & -717.012 & 38.900 & -1.879 & 92.750 \\
\hline Taiw an & 44.109 & 22.962 & 654.287 & -703.730 & 147.909 & 0.062 & 5.397 \\
\hline \multicolumn{8}{|c|}{ Daily Total Return (\%) } \\
\hline Korea & 0.115 & 0.098 & 9.587 & -11.457 & 1.834 & -0.091 & 5.831 \\
\hline India & 0.091 & 0.124 & 8.615 & -11.264 & 1.442 & -0.580 & 8.264 \\
\hline Thailand & 0.100 & 0.038 & 11.094 & -16.544 & 1.636 & -0.318 & 11.988 \\
\hline Taiw an & 0.043 & 0.000 & 6.524 & -6.616 & 1.602 & 0.107 & 4.666 \\
\hline M SC I W orld & 0.025 & 0.050 & 4.713 & -3.620 & 0.859 & 0.065 & 5.782 \\
\hline \multicolumn{8}{|l|}{ Panel B } \\
\hline \multicolumn{8}{|c|}{ First Sample $(01 / 01 / 2001-31 / 12 / 2003)$} \\
\hline \multicolumn{8}{|c|}{ Daily Average Net Foreign Equity Portfolio Investment (USD Millions) } \\
\hline Korea & 2.160 & 0.592 & 64.639 & -91.166 & 13.428 & -0.384 & 11.335 \\
\hline India & 9.841 & 5.183 & 262.340 & -86.639 & 25.256 & 2.157 & 17.828 \\
\hline Thailand & 0.350 & -0.111 & 78.135 & -102.278 & 13.441 & 0.038 & 11.343 \\
\hline Taiw an & 33.222 & 12.701 & 524.051 & -295.647 & 100.496 & 0.802 & 5.087 \\
\hline \multicolumn{8}{|c|}{ Daily Total Return (\%) } \\
\hline Korea & 0.117 & 0.086 & 9.587 & -11.457 & 2.089 & -0.059 & 5.117 \\
\hline India & 0.070 & 0.084 & 8.615 & -11.264 & 1.433 & -0.690 & 9.405 \\
\hline Thailand & 0.127 & 0.047 & 7.813 & -5.585 & 1.674 & 0.244 & 4.365 \\
\hline Taiw an & 0.042 & -0.029 & 6.524 & -6.616 & 1.817 & 0.168 & 4.024 \\
\hline M SC I W orld & 0.008 & 0.045 & 4.713 & -3.620 & 0.983 & 0.120 & 5.013 \\
\hline \multicolumn{8}{|l|}{ Panel C } \\
\hline \multicolumn{8}{|c|}{ Second Sample $(01 / 01 / 2004-30 / 03 / 2007)$} \\
\hline \multicolumn{8}{|c|}{ Daily Average Net Foreign Equity Portfolio Investment (USD Million) } \\
\hline Korea & 2.10 & 0.56 & 94.18 & -65.26 & 16.65 & 0.66 & 7.39 \\
\hline India & 36.65 & 27.84 & 776.77 & -633.60 & 97.32 & 1.01 & 19.05 \\
\hline Thailand & 5.39 & 0.94 & 394.50 & -717.01 & 52.31 & -1.62 & 54.93 \\
\hline Taiw an & 54.19 & 36.35 & 654.29 & -703.73 & 180.53 & -0.18 & 4.28 \\
\hline \multicolumn{8}{|c|}{ Daily Total Return (\%) } \\
\hline Korea & 0.107 & 0.153 & 6.370 & -7.065 & 1.420 & -0.377 & 4.933 \\
\hline India & 0.113 & 0.197 & 8.615 & -11.264 & 1.517 & -0.693 & 9.867 \\
\hline Thailand & 0.038 & 0.012 & 11.094 & -16.544 & 1.580 & -1.059 & 20.949 \\
\hline Taiw an & 0.046 & 0.021 & 6.524 & -6.616 & 1.307 & -0.313 & 6.280 \\
\hline M SC I W orld & 0.055 & 0.067 & 2.095 & -2.477 & 0.584 & -0.222 & 4.009 \\
\hline
\end{tabular}


Table 2

Unconditional correlation between domestic return and world return

Full Sample First Sample $\quad$ Second Sample $\quad \begin{gathered}\text { Percent Change in } \\ \text { Correlation }\end{gathered}$

between Two Sub Samples

\begin{tabular}{lllll}
\hline Korea & 0.248 & 0.221 & 0.325 & $47 \%$ \\
India & 0.192 & 0.158 & 0.273 & $73 \%$ \\
Thailand & 0.173 & 0.140 & 0.254 & $81 \%$ \\
Taiwan & 0.199 & 0.171 & 0.272 & $60 \%$ \\
& & & & \\
\hline
\end{tabular}


Table 3

Unit Root Tests: Full Sample Period (01/01/2001 - 30/03/2007)

Panel A: ADF Test Statistic (Lags 10 and Trend Allowed)

\begin{tabular}{lcccc}
\hline & \multicolumn{2}{c}{ Level Data } & \multicolumn{2}{c}{ First Difference } \\
\hline & $\begin{array}{c}\text { Total } \\
\text { Return } \\
\text { Index }\end{array}$ & $\begin{array}{c}\text { Net Foreign } \\
\text { Equity } \\
\text { Investment }\end{array}$ & $\begin{array}{c}\text { Total Return } \\
\text { Index }\end{array}$ & $\begin{array}{c}\text { Net Foreign } \\
\text { Equity } \\
\text { Investment }\end{array}$ \\
\hline World & -2.116 & N/A & -12.888 & N/A \\
India & -1.740 & -1.574 & -12.009 & -9.744 \\
Korea & -1.706 & -1.221 & -12.661 & -8.977 \\
Thailand & -2.758 & -0.829 & -12.342 & -8.987 \\
Taiwan & -2.115 & -1.436 & -13.321 & -9.580 \\
\hline
\end{tabular}

Critical Value $(1 \%)=-3.96$

Critical Value $(5 \%)=-3.41$

Panel B: Phillip Perron Test Statistic

\begin{tabular}{lcccc}
\hline World & -5.335 & $\mathrm{~N} / \mathrm{A}$ & -1353.924 & $\mathrm{~N} / \mathrm{A}$ \\
India & -4.500 & -1.877 & -1499.024 & -1549.160 \\
Korea & -8.213 & -1.659 & -1555.851 & -1208.984 \\
Thailand & -0.938 & -0.377 & -1695.183 & -1006.503 \\
Taiwan & -11.234 & -2.021 & -1655.035 & -1013.351 \\
\hline
\end{tabular}

Critical Value $(1 \%)=-20.50$

Critical Value $(5 \%)=-21.80$

Panel C: Kwiatkowski, Phillips, Schmidt and Shin (KPSS)

\begin{tabular}{lcccc}
\hline World & & & & \\
Lag 1 & 15.900 & N/A & 0.049 & N/A \\
Lag 10 & 2.940 & N/A & 0.050 & N/A \\
India & & & & \\
Lag 1 & 17.500 & 19.000 & 0.021 & 0.340 \\
Lag 10 & 3.230 & 3.470 & 0.020 & 0.137 \\
Korea & & & & \\
Lag 1 & 9.510 & 8.830 & 0.042 & 0.344 \\
Lag 10 & 1.780 & 1.610 & 0.047 & 0.175 \\
Thailand & & & & \\
Lag 1 & 6.760 & 16.900 & 0.037 & 0.301 \\
Lag 10 & 1.270 & 3.090 & 0.040 & 0.126 \\
Taiwan & & & & \\
Lag 1 & 6.890 & 15.800 & 0.035 & 0.116 \\
Lag 10 & 1.290 & 2.890 & 0.035 & 0.048 \\
\hline
\end{tabular}

Critical Value $(1 \%)=0.216$

Critical Value $(5 \%)=0.146$ 
Table 4

Bivariate Cointegration Test (Domestic and World Return Index)

\begin{tabular}{lcccccc}
\hline & \multicolumn{2}{c}{ Eigenvalues } & \multicolumn{2}{c}{$\lambda_{\text {trace }}$ test } & \multicolumn{2}{c}{$\lambda_{\max }$ test } \\
& $\mathrm{r}=0$ & $\mathrm{r} \leq 1$ & $\mathrm{r}=0$ & $\mathrm{r} \leq 1$ & $\mathrm{r}=0$ & $\mathrm{r}=1$ \\
\hline Full Sample & & & & & & \\
\hline India & 0.015 & 0.000 & $24.070^{*}$ & 0.017 & $24.057^{*}$ & 0.017 \\
Korea & 0.007 & 0.000 & 11.805 & 0.007 & 11.798 & 0.007 \\
Taiwan & 0.008 & 0.003 & $17.160^{*}$ & 3.378 & $14.781^{*}$ & 2.378 \\
Thailand & 0.006 & 0.000 & 10.847 & 0.715 & 10.132 & 0.715 \\
\hline
\end{tabular}

First Sample

\begin{tabular}{|c|c|c|c|c|c|c|}
\hline India & 0.006 & 0.001 & 5.067 & 0.686 & 4.381 & 0.686 \\
\hline Korea & 0.009 & 0.002 & 8.380 & 1.491 & 6.889 & 1.491 \\
\hline Taiwan & 0.007 & 0.005 & 8.906 & 3.671 & 5.235 & 3.671 \\
\hline Thailand & 0.006 & 0.002 & 6.619 & 1.891 & 4.728 & 1.891 \\
\hline \multicolumn{7}{|c|}{ Second Sample } \\
\hline$\overline{\text { India }}$ & 0.021 & 0.000 & $17.905^{*}$ & 0.004 & $17.901^{*}$ & 0.004 \\
\hline Korea & 0.004 & 0.000 & 3.015 & 0.010 & 3.005 & 0.010 \\
\hline Taiwan & 0.019 & 0.000 & $16.544^{*}$ & 0.000 & $16.544^{*}$ & 0.000 \\
\hline Thailand & 0.010 & 0.000 & 8.876 & 0.056 & 8.819 & 0.056 \\
\hline \multicolumn{3}{|c|}{ Critical Value at } & 15.495 & 3.841 & 14.265 & 3.841 \\
\hline
\end{tabular}


Table 5

Trivariate Cointegration Test (Net Foreign Equity Trading, Domestic and World Return Index) Cointegration Results - Domestic Return Index, World Return Index and Foreign Equity Trading

\begin{tabular}{|c|c|c|c|c|c|c|c|c|c|}
\hline & \multicolumn{3}{|c|}{ Eigenvalues } & \multicolumn{3}{|c|}{$\lambda_{\text {trace }}$ Test } & \multicolumn{3}{|c|}{$\lambda_{\max }$ Test } \\
\hline & $\mathrm{r}=0$ & $\mathrm{r} ? 1$ & r? 3 & $\mathrm{r}=0$ & r? 1 & r? 3 & $\mathrm{r}=0$ & $\mathrm{r}=1$ & $r=3$ \\
\hline \multicolumn{10}{|c|}{$\overline{\text { Full Sample }}$} \\
\hline$\overline{\text { India }}$ & 0.022 & 0.004 & 0.000 & $43.864 *$ & 7.332 & 0.009 & $36.533^{*}$ & 7.323 & 0.009 \\
\hline Korea & 0.015 & 0.004 & 0.000 & $30.695^{*}$ & 6.511 & 0.569 & $24.184 *$ & 5.942 & 0.569 \\
\hline Taiwan & 0.037 & 0.007 & 0.000 & $72.363^{*}$ & 11.842 & 0.033 & $60.521 *$ & 11.809 & 0.033 \\
\hline Thailand & 0.022 & 0.005 & 0.000 & $44.575^{*}$ & 8.493 & 0.536 & $36.082 *$ & 7.956 & 0.536 \\
\hline \multicolumn{10}{|c|}{ First Sample } \\
\hline India & 0.0788 & 0.0119 & 0.0041 & $76.332 *$ & 12.4826 & 3.1876 & $63.849 *$ & 9.2949 & 3.1876 \\
\hline Korea & 0.0355 & 0.0221 & 0.0000 & $45.845^{*}$ & 14.5636 & 0.0482 & $28.281 *$ & $17.5154 *$ & 0.0482 \\
\hline Taiwan & 0.0340 & 0.0082 & 0.0013 & $34.336^{*}$ & 7.4521 & 1.0375 & $26.884^{*}$ & 6.4146 & 1.0375 \\
\hline Thailand & 0.0321 & 0.0087 & 0.0022 & $33.914 *$ & 8.5023 & 1.6744 & $25.411^{*}$ & 6.8278 & 1.6744 \\
\hline \multicolumn{10}{|c|}{ Second Sample } \\
\hline India & 0.0270 & 0.0206 & 0.0006 & $41.188^{*}$ & $18.047^{*}$ & 0.4747 & $23.140^{*}$ & $17.573^{*}$ & 0.4747 \\
\hline Korea & 0.0340 & 0.0036 & 0.0000 & $32.347^{*}$ & 3.0590 & 0.0401 & $29.287 *$ & 3.0180 & 0.0401 \\
\hline Taiwan & 0.0272 & 0.0215 & 0.0002 & $41.854 *$ & $18.537^{*}$ & 0.1380 & $23.317 *$ & $18.398^{*}$ & 0.1380 \\
\hline Thailand & 0.0822 & 0.0231 & 0.0003 & $92.567^{*}$ & $19.961^{*}$ & 0.2199 & $72.605^{*}$ & $19.741^{*}$ & 0.2199 \\
\hline \multicolumn{4}{|c|}{ Critical values at $95 \%$} & 29.80 & 15.49 & 3.84 & 21.13162 & 14.2646 & 3.841466 \\
\hline
\end{tabular}


Table 6

Final Cointegration Result

Full Sample - 01/01/2001 - 30/03/2007

\begin{tabular}{lcc} 
& World Return Index & World Return Index and Net Foreign Equity Purchase \\
\hline India & One & One \\
Korea & None & One \\
Taiwan & One & One \\
Thailand & None & One
\end{tabular}

First Sample - 01/01/2001 - 31/12/2003

\begin{tabular}{lcc} 
& World Return Index & World Return Index and Net Foreign Equity Purchase \\
\hline India & None & One \\
Korea & None & One \\
Taiwan & None & One \\
Thailand & None & One \\
& \multicolumn{2}{c}{ Second Sample - 01/01/2004 - 30/03/2007 } \\
& \multicolumn{3}{c}{ World Return Index and Net Foreign Equity Purchase } \\
\hline & World Return Index & Two \\
India & One & One \\
Korea & None & Two \\
Taiwan & One & Two \\
Thailand & None &
\end{tabular}

Table 7

Granger Causality and ECM Result (Full Sample)

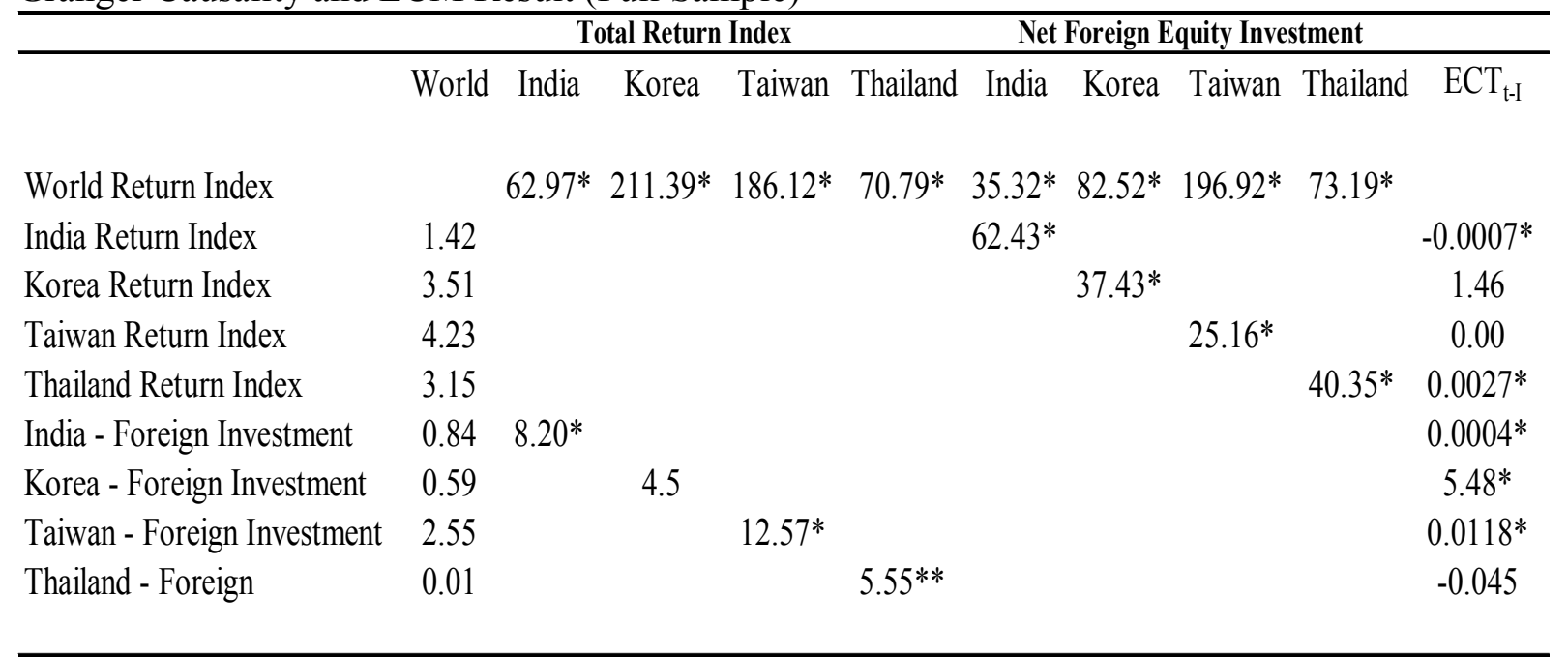

*(**) Indicates Significance of the Chi-Square (t-for ECT) Statistic at 95\%(90\%) 
Table 8

Variance Decomposition

\begin{tabular}{|c|c|c|c|c|c|c|}
\hline Period & $\begin{array}{l}\text { World } \\
\text { Return }\end{array}$ & $\begin{array}{c}\text { Domestic } \\
\text { Return }\end{array}$ & $\begin{array}{l}\text { Net Equity } \\
\text { Investment }\end{array}$ & $\begin{array}{l}\text { World } \\
\text { Return }\end{array}$ & $\begin{array}{c}\text { Domestic } \\
\text { Return }\end{array}$ & $\begin{array}{l}\text { Net Equity } \\
\text { Investment }\end{array}$ \\
\hline \multicolumn{4}{|c|}{ India } & \multicolumn{3}{|c|}{ Korea } \\
\hline & \multicolumn{3}{|c|}{ Domestic Return } & \multicolumn{3}{|c|}{ Domestic Return } \\
\hline 1 & 5.665 & 90.691 & 3.644 & 8.192 & 91.808 & O.OOO \\
\hline 5 & 33.461 & 61.493 & 5.047 & 39.096 & 60.790 & O. 114 \\
\hline 10 & 40.398 & 53.706 & 5.896 & 42.391 & 57.525 & 0.084 \\
\hline 15 & 44.113 & 49.748 & 6.139 & 43.403 & 56.527 & 0.069 \\
\hline 20 & 46.911 & 46.872 & 6.218 & 43.871 & 56.069 & 0.059 \\
\hline & Net Fore & gn Equity & Investment & Net Fore & gn Equity & Investment \\
\hline 1 & 0.144 & O.OOO & 99.856 & 0.161 & 0.509 & 99.330 \\
\hline 5 & 11.176 & 1.521 & 87.302 & 12.296 & 8.885 & 78.819 \\
\hline 10 & 14.241 & 2.192 & 83.567 & 16.894 & 10.473 & 72.633 \\
\hline 15 & 14.681 & 2.865 & 82.454 & 18.457 & 11.770 & 69.773 \\
\hline \multirow[t]{2}{*}{20} & 14.583 & 3.549 & 81.867 & 19.373 & 13.043 & 67.584 \\
\hline & \multicolumn{3}{|c|}{ World Return } & \multicolumn{3}{|c|}{ World Return } \\
\hline 1 & 100.000 & O.OOO & O.OOO & 100.000 & O.OOO & O.OOO \\
\hline 5 & 99.932 & 0.020 & 0.048 & 99.931 & 0.030 & 0.039 \\
\hline 10 & 99.904 & 0.071 & 0.025 & 99.912 & 0.027 & 0.061 \\
\hline 15 & 99.813 & 0.170 & O.O17 & 99.907 & 0.025 & 0.067 \\
\hline 20 & 99.684 & 0.303 & 0.013 & 99.906 & 0.024 & 0.070 \\
\hline \multicolumn{4}{|c|}{ Taiwan } & \multicolumn{3}{|c|}{ Thailand } \\
\hline & \multicolumn{3}{|c|}{ Domestic Return } & \multicolumn{3}{|c|}{ Domestic Return } \\
\hline 1 & 3.086 & 83.380 & 13.534 & 2.343 & 76.666 & 20.991 \\
\hline 5 & 24.010 & 60.100 & 15.890 & 12.156 & 71.207 & 16.637 \\
\hline 10 & 26.701 & 57.000 & 16.299 & 13.779 & 69.641 & 16.580 \\
\hline 15 & 27.561 & 56.002 & 16.437 & 14.411 & 69.039 & 16.551 \\
\hline 20 & 27.982 & 55.511 & 16.508 & 14.803 & 68.700 & 16.497 \\
\hline & Net Fore & gn Equity & Investment & Net Fore & gn Equity & nvestment \\
\hline 1 & 0.577 & O.OOO & 99.423 & O. 140 & O.OOO & 99.860 \\
\hline 5 & 15.172 & 0.873 & 83.955 & 4.573 & 1.329 & 94.098 \\
\hline 10 & 18.767 & 1.093 & 80.140 & 5.396 & 1.553 & 93.051 \\
\hline 15 & 20.948 & 1.241 & 77.811 & 5.613 & 1.650 & 92.738 \\
\hline \multirow[t]{2}{*}{20} & 22.836 & 1.375 & 75.789 & 5.688 & 1.717 & 92.595 \\
\hline & \multicolumn{3}{|c|}{ World Return } & \multicolumn{3}{|c|}{ World Return } \\
\hline 1 & 100.000 & O.OOO & O.OOO & 100.000 & O.OOO & O.OOO \\
\hline 5 & 99.939 & 0.014 & 0.046 & 99.727 & 0.260 & 0.013 \\
\hline 10 & 99.954 & 0.020 & 0.026 & 99.722 & 0.270 & 0.008 \\
\hline 15 & 99.950 & 0.026 & 0.024 & 99.756 & 0.237 & 0.006 \\
\hline 20 & 99.938 & 0.032 & 0.030 & 99.790 & 0.201 & 0.009 \\
\hline
\end{tabular}


Figure 1

Rolling Correlation between Indian Domestic Return and World Return

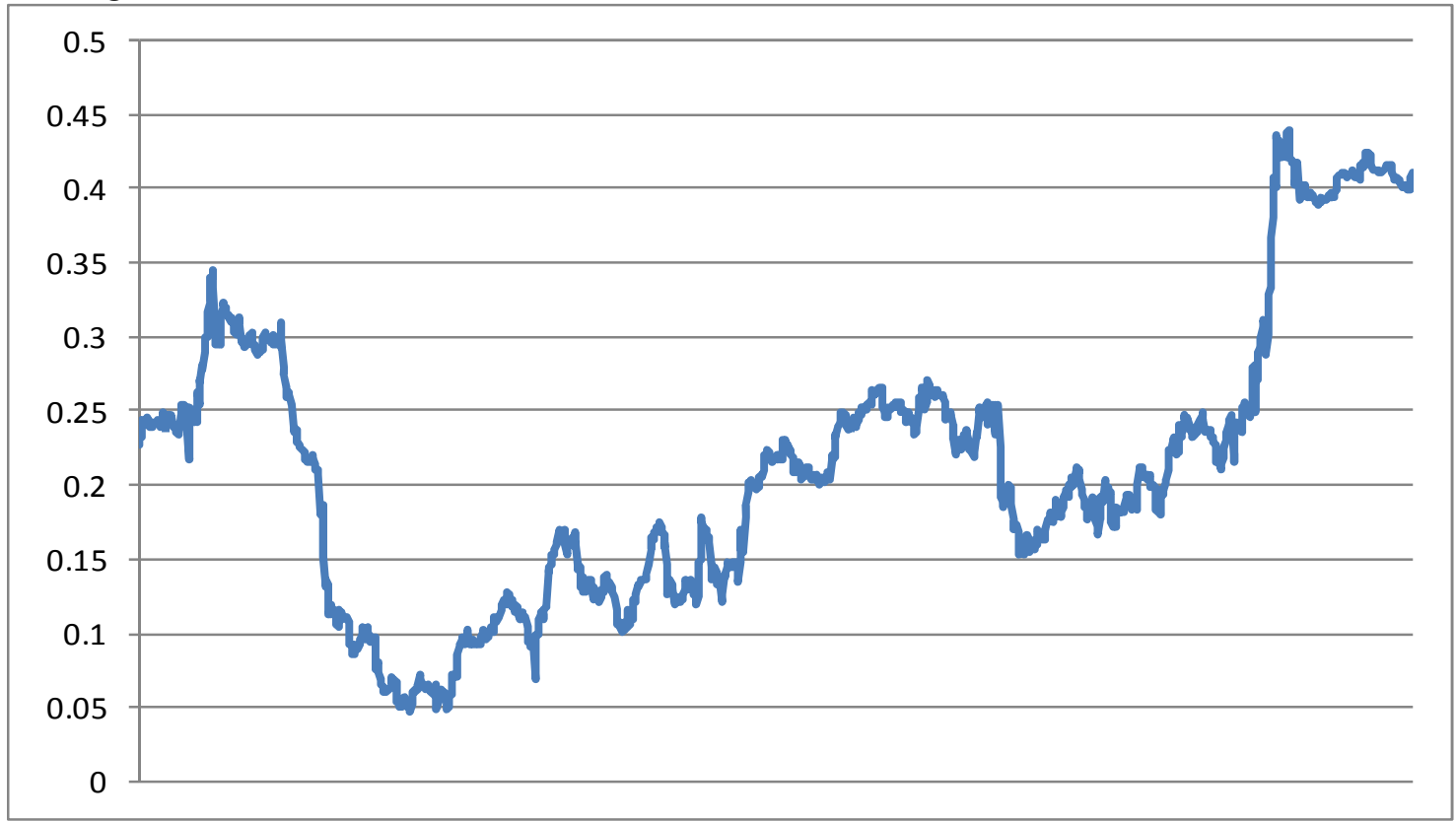

Figure 2

Rolling Correlation between Korean Domestic Return and World Return

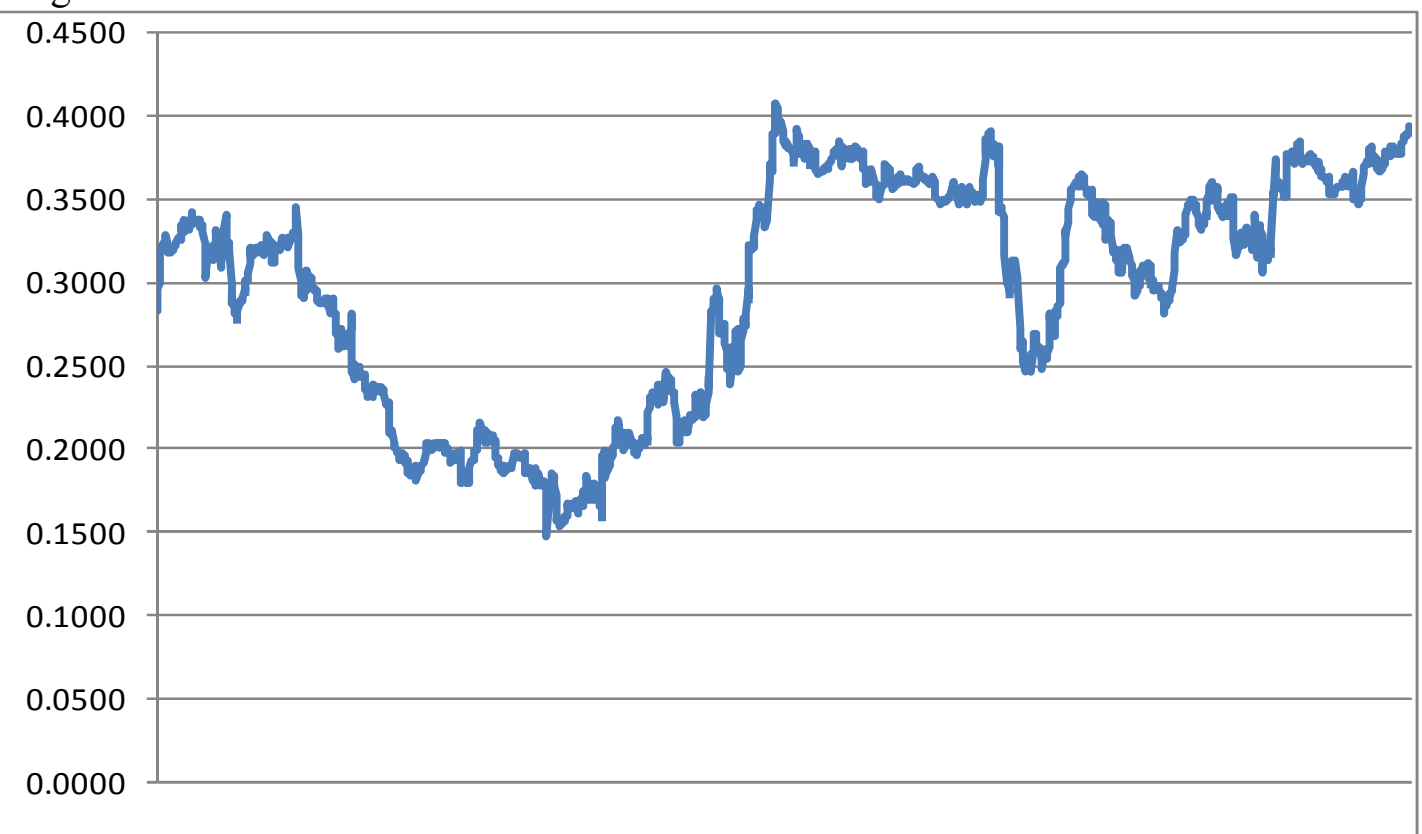


Figure 3

Rolling Correlation between Taiwanese Domestic Return and World Return

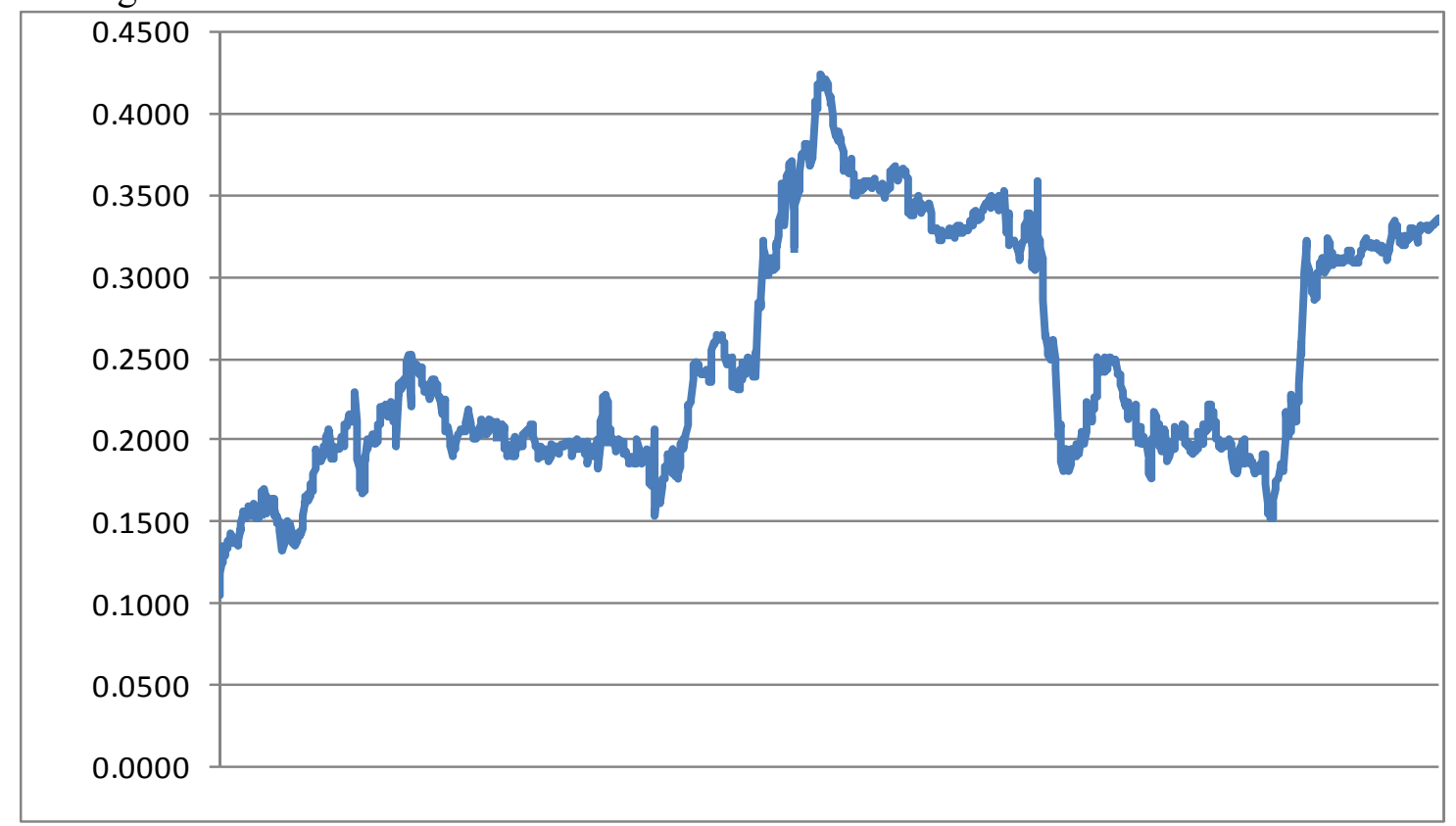

Figure 4

Rolling Correlation between Thai Domestic Return and World Return

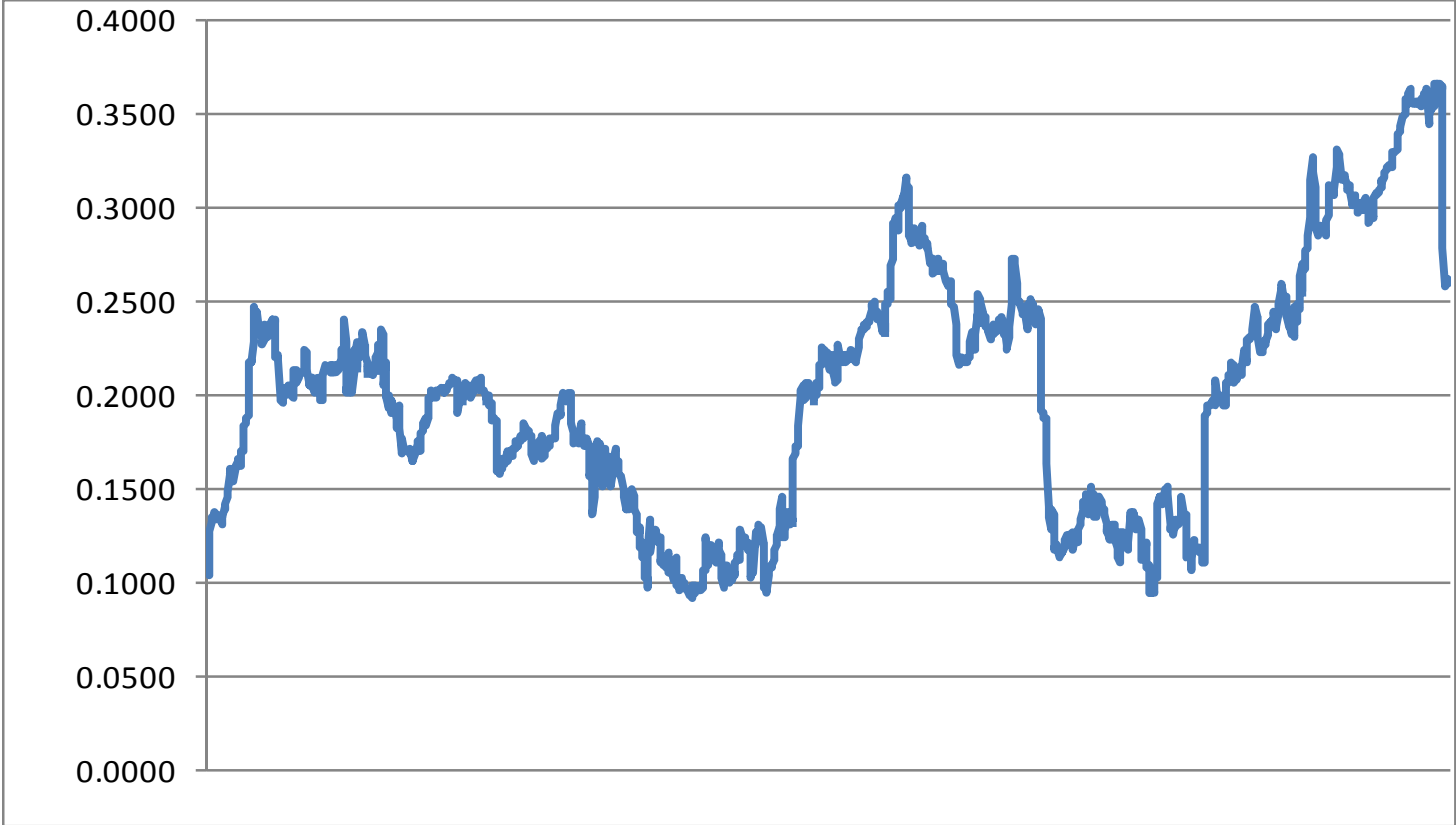


Figure 5

Impulse Response Function - India

$$
\text { Response of Domest ic Returns to lags of: }
$$
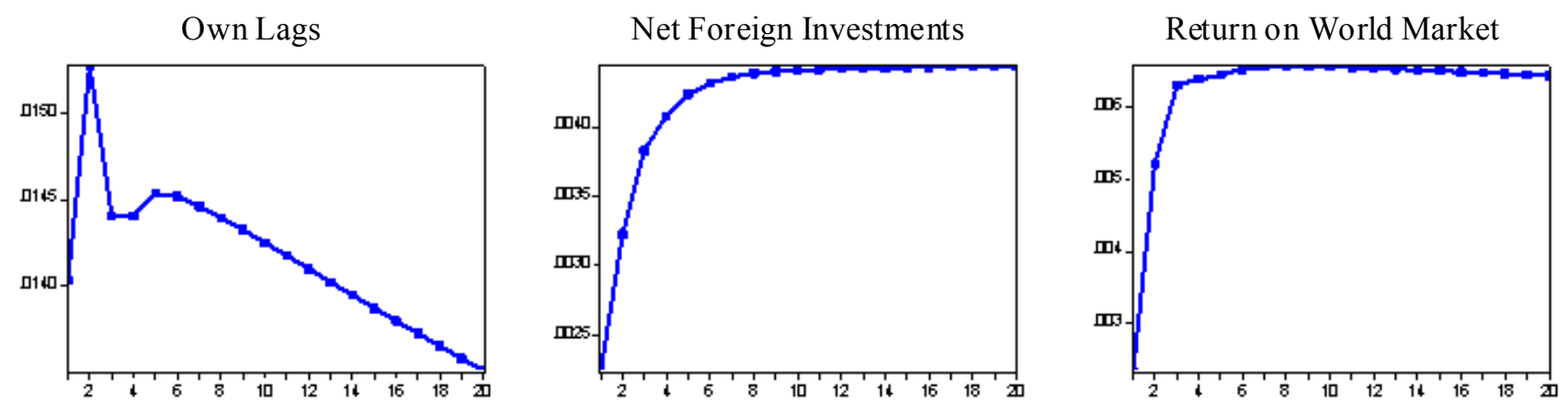

Response of Net Foreign Investments to lags of:
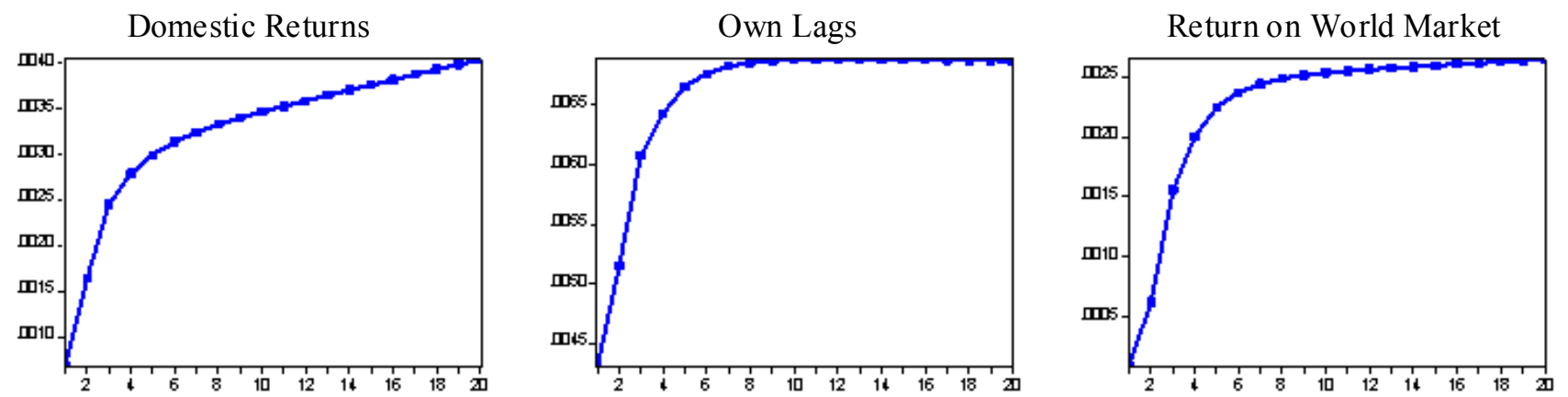
Figure 6

Impulse Response Function - South Korea

Response of Domest ic Returns to lags of:
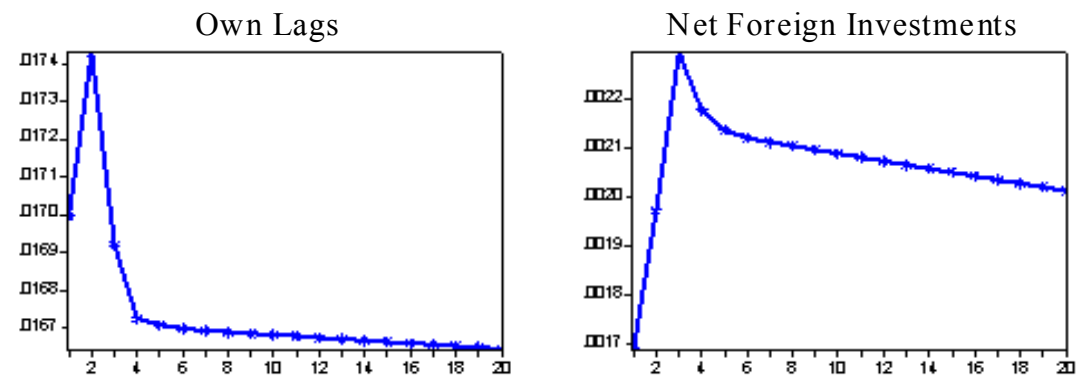

Return on World Market

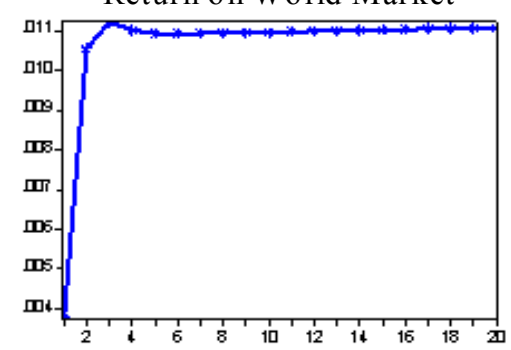

Response of Net Foreign Investments to lags of:

Domestic Returns

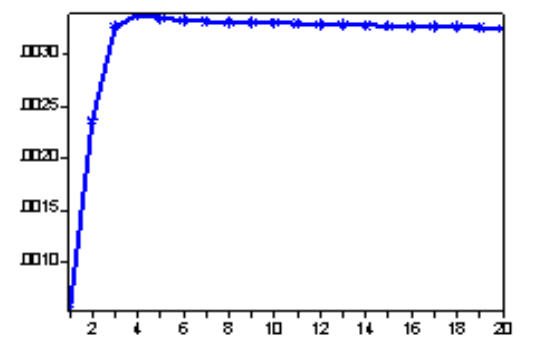

Own Lags

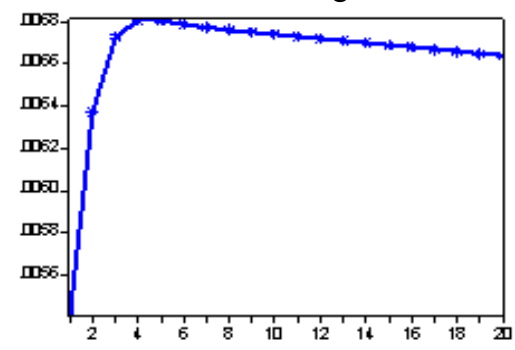

Return on World Market

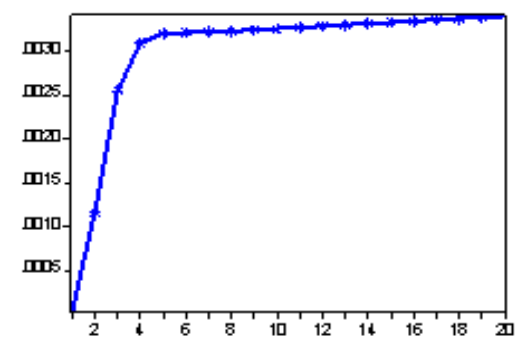


Figure 7

Impulse Response Function - Thailand

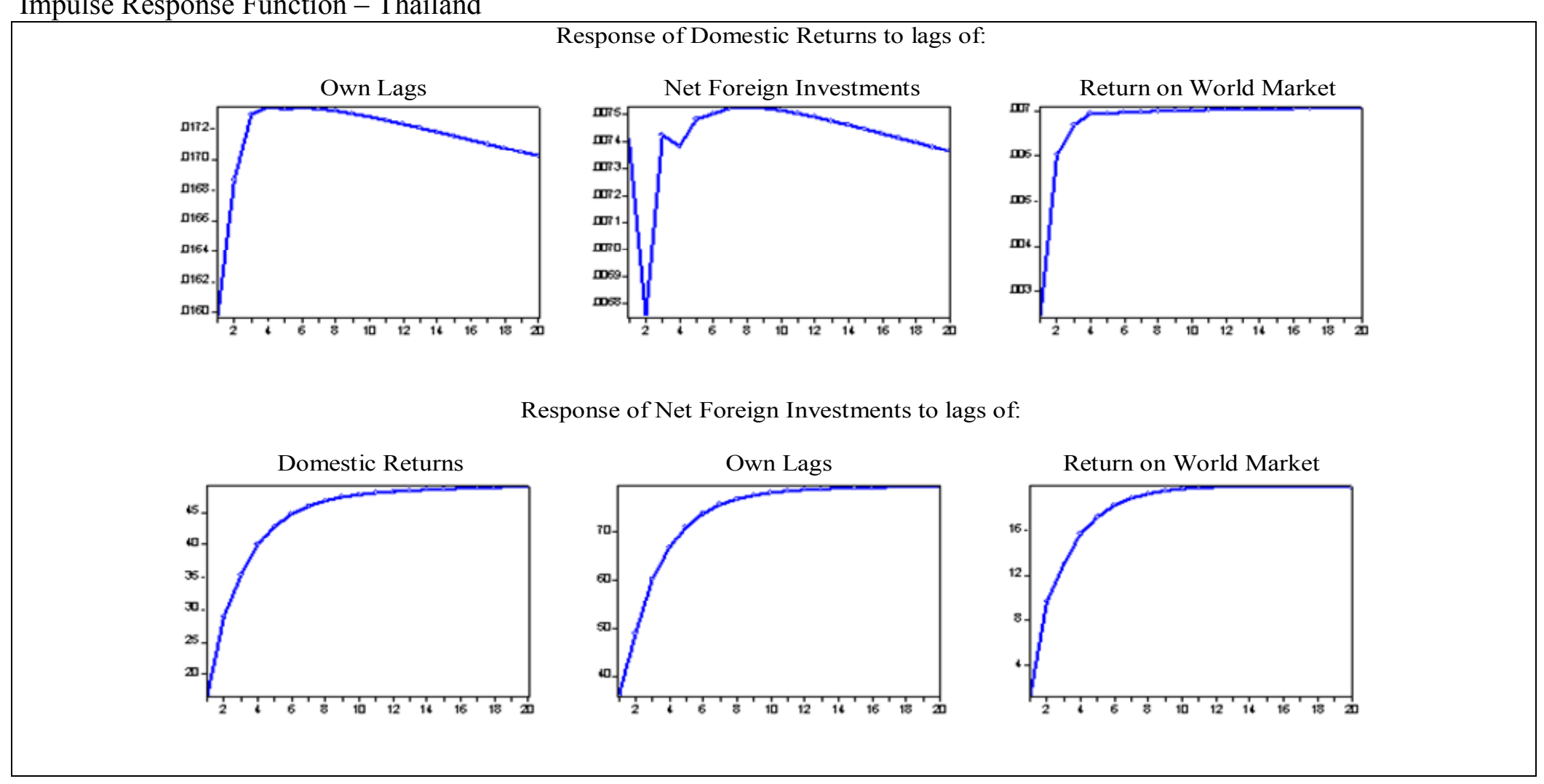


Figure 8

Impulse Response Function - Taiwan

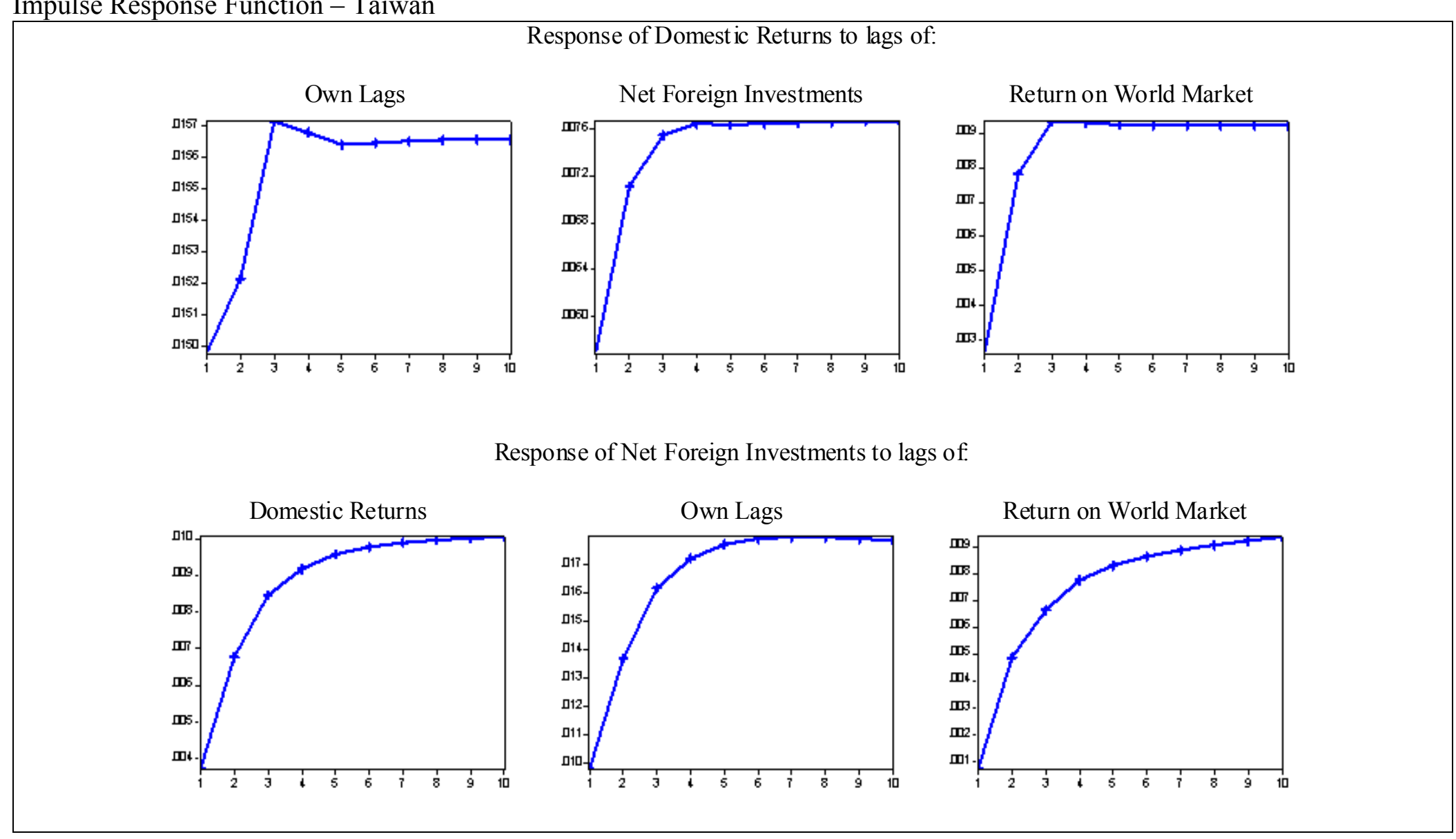

